\title{
CHINA'S POLICY ON DEVELOPMENT AND SECURITY IN EAST AFRICA
}

\author{
Liselotte Odgaard ${ }^{1}$ \\ Danish Foreign Policy Society
}

\begin{abstract}
This article argues that China's Eastern Africa policy is based on Chinese national economic and strategic interests - but with significant contributions to regional order. Beijing couples its One Belt One Road (OBOR) initiative and existing United Nations (UN) policies to ensure that economic development projects are linked to Chinese contributions to regional peace and stability. China contributes to regional order by emphasising the use of military force for defensive purposes only and by gaining pre-approval from the region for such interventions. It also provides strong government-backed economic and diplomatic assistance to African countries, to further foster such regional order. Yet, contrary to its stated intentions, Beijing's focus on development and non-interference could pose challenges to human rights observance and issues of social justice - by potentially allowing rogue regimes to jeopardise the basic security of individuals. In turn, this could further challenge regional order by spreading instability and conflict across borders.
\end{abstract}

Keywords: China, East Africa, One Belt One Road, English School, United Nations.

\section{Introduction}

China's Eastern Africa ${ }^{2}$ policy is not merely aimed at protecting Chinese economic and security interests. Beijing also focuses on providing development and stability that benefit local communities. This article addresses the question how China reconciles the dilemmas arising from potentially conflicting demands from China's foreign policy doctrines and the overseas context in which Chinese policies are implemented. For example, Beijing's support for an African security architecture to promote security and stability as a basis for development creates dilemmas for China. Regional forums, such as the African Union (AU), demand more robust and offensive United Nation (UN) operations. Such demands clash with China's preference for a defensive security posture based on strict adherence to noninterference. ${ }^{3}$ The policy of non-interference has allowed China to establish a global economic engagement irrespective of political, social or economic differences with recipient countries. Beijing's answer to these dilemmas is to become increasingly engaged in designing and providing for regional order and economic development. Regional order consists of basic rules of conduct that benefit the common interest of states in peace and security. China is a pioneer with its concept of regional order in East Africa, which couples its UN policy with its One Belt One Road (OBOR) 
initiative. China's UN policy emphasises diplomacy and defensive military force as tools for preventing atrocities against civilians and for promoting peace. The OBOR initiative provides regional economic infrastructure and communication links to enhance growth and welfare. In China's view, this constitutes a coherent framework for the provision of the characteristics, which China sees as necessary elements in regional order: economic development, peace and stability for China as well as for the countries in which China is engaged.

I use the theoretical approach of the English School to examine whether China builds strategic partnerships in East Africa that not merely benefit Chinese national interests, but also facilitate regional peace and security. The English School addresses the nexus between dynamics of power politics engendering competition for relative power and community dynamics that, in turn, may create political frameworks to facilitate peace and security. I address China's Eastern Africa policy and its interplay with the UN by discussing China's contributions to regional order through initiatives in peacekeeping, economic development and diplomacy based on a state-centred approach to enhancing development and security. I focus on the extent to which these policies serve not merely China's national interest, but also the common interest in development and security. In conclusion, I assess the strengths and weaknesses in China's attempt to contribute to regional order in East Africa.

\section{An English School perspective on order in international politics}

The English School argues that, despite the prevalence of international anarchy, states behave as a community by regulating their interaction to promote peace and security. ${ }^{4}$ States regulate their interaction by agreeing on common rules of conduct. These constraints on state actions imply that states accept responsibility for protecting international peace and security, even if at times, this obligation requires that they forgo short-term national interests. ${ }^{5}$

According to the English School, security dilemmas can be overcome because states realise that agreement on basic rules of conduct benefits their common interest in peace and security and helps them survive. A state's goodwill vis-à-vis other states and its status as a worthy partner, form the basis for successful interaction with others. Consequently, reputation is an asset that states cannot afford to take lightly. ${ }^{6}$ International order requires rules that regulate the use of force of jurisdiction between political authorities and of the sanctity of agreements. ${ }^{7}$ Limitations on the use of force ensure that peace remains the normal condition in the international system. Constraints on the use of force do not necessarily prevent war. However, constraints may avert and control crises and prevent wars between lesser powers that, ultimately, may involve great powers. Constraints may therefore entail efforts such as conflict prevention and peacekeeping.

Definitions of jurisdiction ensure clarity about the entities that have legitimate political authority and are responsible for maintaining international order. Legitimacy concerns the assessment by the international community of the entities entitled to 
claim sovereign rights over a territory and its population. ${ }^{8}$ Economic transnational dynamics influence assessments of regime legitimacy. This happens because states are responsible for the protection of the basic rights of individuals to livelihood and to exercise political influence and not just for the preservation of the state system. Economic responsibilities transcend borders because economic and financial crises spread across the world swiftly, engendering a need for economic justice in the relationship between developed and developing countries. ${ }^{9}$ The emergence of transnational concepts of justice implies that economic legitimacy issues addressed by broad approaches to legitimacy are seen as particularly important aspects that cannot be separated from the political aspects of legitimacy.

Definitions of the sanctity of agreements ensure that treaties and other statements that clarify the rights and obligations of states form the basis for international institutional arrangements. International institutions for policy coordination on security issues are helpful to ensure peace and stability. Common organisations are necessary to carry out security management. They can be informal, such as the ad hoc conferences used during the nineteenth century European Concert. ${ }^{10}$ Common organisations could also be formal, such as the series of arms control negotiations that took place between the United States and the Soviet Union during the Cold War. The decision of states to remain within rule-bound limits is not a question of law but of politics, and contemporary political agreements are often negotiated in the context of informal and formal organisations. ${ }^{11}$

Accordingly, Chinese contributions to regional order in East Africa, which provide peace and security, require policies on the use of force, legitimacy and institutional arrangements that are compatible in the sense of facilitating security management among regional states and international actors. The English School examines the question whether states provide platforms for policy coordination that address key security issues, keeping a lid on potential conflicts, and facilitating cooperation. ${ }^{12}$ This makes the school useful for investigating the question whether China builds strategic partnerships in East Africa that do not merely benefit Chinese national interests, but also facilitate regional peace and security. In the following sections, I examine China's approach to East African order and the extent to which this order is implemented by means of Chinese peacekeeping efforts, by economic development efforts, and by using diplomatic institutions as an instrument of peace and security.

\section{China's approach to East African order: OBOR and the UN combined}

China's OBOR initiative is effectively a grand plan to link 4,4 billion people and more than 60 countries stretching from Beijing to Europe, through Central Asia, the Middle East and Africa, in a modern version of the land and maritime Silk Roads. The initiative is to put China at the centre of a global network of interconnections. ${ }^{13}$ OBOR is based on Chinese standards of governance that are negotiated as the project unfolds and in cooperation with the partner countries. 
OBOR is one of the major initiatives of China's Xi Jinping administration. ${ }^{14}$ The main objective of OBOR is to establish an alternative to the liberal free trade projects of Western states and institutions, or in the least, to conform to neoliberalism with 'Chinese characteristics'. ${ }^{15}$ This alternative includes technology sharing, frequent demands for compulsory partnerships between foreign and domestic actors, strong state-owned companies, and tight capital control. Additional objectives encompass the expansion of China's overseas markets and increasing Chinese sources of energy supplies. Moreover, an important objective entails promoting financial stability by establishing principles of conduct at a time when China is increasingly exposed to financial risk. ${ }^{16}$ OBOR encompasses private market-driven projects and economic development projects. The latter type dominates the East African part of OBOR. The objective of stability is key to China's willingness to allocate resources to projects that may not be economically viable.

OBOR has been criticised for not having a clear set of rules to guide its activities and clarify its purpose, objectives and instruments to other states. ${ }^{17}$ This may be true. For example, the absence of clear rules is strategically useful since it allows Beijing to adopt flexible approaches depending on local and historical conditions. ${ }^{18}$ Other voices have pointed out that OBOR is a label for ongoing projects rather than an attempt to establish grand new projects. ${ }^{19}$ For example, in East Africa, a number of port and rail projects were agreed before the announcement of OBOR, and both preand post-OBOR projects are established by a mixture of state-owned and private companies; however, labelling matters as an 'OBOR initiative' creates the sense that China is responsible for contributing to economic growth and development.

The strategy constitutes a political superstructure to China's global economic role. This involves defining the principles of governance to ensure that Beijing's influence contributes to peace and stability and not just to China's national interests. East Africa is the part of the maritime Silk Road where China has the most strategic freedom of action. This situation is due to a low level of military-strategic United States (US) involvement and long-standing diplomatic and military links between China and East Africa. ${ }^{20}$

China has hooked up with the UN system in its pursuit of gradual revisions to the existing principles concerning global development and security management. For example, China acknowledges the UN-based Responsibility to Protect (R2P) doctrine on the responsibility to protect populations against atrocity crimes. However, China challenges Western efforts to use the doctrine to legalise the right to intervene without regime consent. Beijing insists that implementation of R2P begins with the responsibility of the state in which atrocity crimes are committed and pursues this interpretation when engaged in peace and stability efforts in states such as South Sudan. ${ }^{21}$ This way of going about exercising influence has several advantages. If China embedded its overseas activities in Sino-centric concepts of world order, Beijing would meet immediate resistance to policies and principles of conduct that have no a priori legitimacy with other states. By contrast, the UN system has universal legitimacy, so China only has to persuade the international community that 
its interpretation of right and wrong conduct is in compliance with the UN Charter. On this basis, China has successfully defended the status of absolute sovereignty and introduced its own policy on how to pursue development and security overseas.

\section{Constraints on the use of force: Peacekeeping efforts}

China's approach is to use the continent-wide forum of the AU as a platform for Africa-wide policy coordination and to facilitate East African bilateral and multilateral intergovernmental projects. The intention is to reconcile human justice and sovereignty by allowing neighbouring states significant influence on how to create security in their local environment. Apart from the deployment of UN troops, China also contributes military and financial assistance to AU peacekeeping endorsed by the UN. In 2015, at the Forum for China-Africa Cooperation, China earmarked US\$100 million for the AU's standby force and the African Capacity for Immediate Response to Crisis (ACIRC). China has also promised to send its first helicopter squad to UN peacekeeping operations in Africa and set up a permanent peacekeeping police squad. ${ }^{22}$ In June 2017, China's helicopter squad joined the United Nations African Union Mission in Darfur (UNAMID). ${ }^{23}$ By September 2017, all of the 300 members of China's standby police force of UN peacekeeping missions had been incorporated into the UN Peacekeeping Capability Readiness System. ${ }^{24}$ Moreover, China donated US\$1,2 billion to improve the welfare for the staff of the AU's mission in Somalia, AMISOM. ${ }^{25}$ These initiatives allow China to participate constructively in resolving hot-button issues in Africa the Chinese way by providing economic assistance for greater regional self-reliance.

China emphasises the importance of the UN in efforts to safeguard African peace and stability. ${ }^{26}$ China's approach to regional order is to use the continent-wide forum of the AU as a flexible platform for policy coordination with Africa as a whole to facilitate bilateral agreements outside of the AU framework. Even when China deployed a permanent mission to the AU in 2015, China mainly consulted with African ambassadors of individual countries, suggesting that the AU does not have a coherent China policy. ${ }^{27}$ Consequently, most of China's East African projects are bilateral intergovernmental or private sector projects. ${ }^{28}$

However, while bolstering China's image as a responsible great power, such involvement and support of regional security architecture also bears the risk of creating a situation in which China will be confronted with its reluctance to support interference in other states' sovereign sphere. This could have been the case with Burundi in 2016 if the collective AU had supported an intervention without the consent of Burundi's government, placing China in a difficult dilemma.

China has around 2600 peacekeepers stationed in UN missions, mostly in Africa. The largest deployment, more than 1000 , serves in South Sudan. Submission of UN peacekeeping personnel to UN authority is important to China to demonstrate that it acts as part of the efforts by the international community to promote peace and security. UN authority is not based on a leadership approach involving a hierarchy 
of intervening powers and one state submitting decision-making authority to another state. Instead, UN efforts are based on the legal equality of states and the authority of the UN Security Council in which China has veto powers. Therefore, China's recognition of $\mathrm{UN}$ authority does not violate its commitment to non-interference.

One element in China's OBOR strategy is to build infrastructure facilitating intra- and inter-regional economic interaction and peacekeeping initiatives. Djibouti forms a central part of the maritime Silk Road. It has Chinese-built port facilities for commercial and military use. In 2016, Chinese naval and military contingents arrived in Djibouti. China has built its first permanent naval base at the site of the US-built naval pier in the port of Obock. ${ }^{29}$ China has announced that it plans to build additional port facilities. In East Africa, Beijing has approached the Seychelles as a likely partner. Chinese escort ships already halt for supply and rest facilities in the ports of the Seychelles. ${ }^{30}$ Permanent overseas naval facilities serve various purposes. In their capacity as military bases, port facilities could help China realise plans to enable its navy to focus on a combination of offshore waters ('green water') defence and open seas ('blue water') protection, requiring global port facilities. ${ }^{31}$

However, the facilities are also intended as staging points for operations that are overall positive for maritime public goods provided for societal rather than individual consumption, such as humanitarian assistance and disaster relief. This indicates the greater weight placed on acting as a responsible great power emphasising both order and justice. One purpose is to use the facilities as a logistics hub for naval operations to support Chinese anti-piracy operations. Such operations encompass participation by the People's Liberation Army Navy in multination anti-piracy efforts in the Gulf of Aden since 2008. This function is likely to facilitate increasing cooperation between the countries participating in anti-piracy patrols in the Gulf of Aden, the Arabian Sea, and the Indian Ocean to ensure the safe passage of civilian vessels. ${ }^{32}$

China's policy is to adopt only defensive measures and to support African government institutions irrespective of ideological or religious preferences. ${ }^{33}$ The intention is to strengthen the regime's effective control of its sovereign territory and citizenry, emphasising the element of order. In China's view, giving preference to state rights rather than individual rights is likely to minimise violence in the long run, because it keeps a lid on intra-ethnic and intra-religious conflicts. ${ }^{34}$ Following the 2005 peace agreement between northern and southern Sudan, China has contributed peacekeeping personnel to the UN Mission in Sudan (UNMIS). From 2006, China deployed peacekeeping personnel with tasks such as engineering, transportation and medical assignments. ${ }^{35}$ In 2015, China deployed combat troops for the first time to a UN peacekeeping mission by contributing 700 troops to the UN peacekeeping mission in South Sudan (UNMISS) ${ }^{36}$ China still has far less of a military presence than other major powers, such as the US and France, who both have their own military bases in Djibouti. The Chinese troops are not designated as combat forces employing the full range of military instruments. The troops are armed as defensive security forces only. ${ }^{37}$ This means that the Chinese forces are used only for defensive purposes such as the protection of civilians and government buildings and not for offensive purposes. ${ }^{38}$ 
China also supports local military forces, enabling them to protect national sovereignty. For example, in 2015 China donated US\$1 million for the construction of armouries for the Somali National Army. ${ }^{39}$ Beijing's contributions to strengthen weak national militaries in East Africa are accused of increasing violence and unrest on the grounds that China's assistance is targeting government forces. This is Beijing's policy even if the recipient states are placed in the lowest category of the Freedom House index of fragility, political oppression and authoritarian political systems, such as Somalia and Sudan. ${ }^{40}$ For example, the sale in 2014 by China North Industries Corporation (Norinco) of US\$20 million worth of arms and armsrelated material to the Sudan People's Liberation Army (SPLA), the South Sudanese government's armed forces, has engendered criticism for contributing to intrastate violence. However, there is no arms embargo in place on South Sudan, and other countries such as Israel are also arms exporters to South Sudan. ${ }^{41}$ Nevertheless, China halted weapon sales in 2014 in response to the international criticism that China's arms sales undermined the peace process, highlighting the dilemmas between order and justice facing Beijing. ${ }^{42}$

\section{Legitimacy and China's economic development efforts}

One element of China's OBOR initiative is to undertake economic development projects that link economies together by infrastructure and communication without political conditionality. China argues that this strategy helps put developing countries on a viable economic and social footing and facilitates long-term political stability. ${ }^{43}$ The strategy is coupled with China's UN policy of focusing on both pre- and postintervention stabilisation measures such as social, economic and reconstruction efforts under the auspices of the UN system. China has a substantial and longstanding presence in East Africa. Beijing argues that this long-standing engagement gives it detailed economic, social and political knowledge that makes development assistance effective. Africa has become China's second largest supplier of crude oil. The top African suppliers are Angola and Sudan. ${ }^{44}$ Sudan is also among China's top five African trade partners. When South Sudan, host of a large number of Chinese oil investments, seceded from Sudan with UN approval in 2011, China also extended development projects and loans to this new state. ${ }^{45}$

South Sudan is a welcome opportunity for China to implement its development policy in an area with relatively limited engagement from other states. China is willing to accept conditions, such as a very low per-barrel oil fee without the promise of rights to future reserves. This is possible when Chinese state-owned companies are involved because they do not answer to shareholders. A caveat to China's ability to influence conditions in this country is the comparative lack of popularity of China amongst the South Sudanese public compared to China's standing in other African countries. ${ }^{46}$ One reason for China's bad reputation is Beijing's role as a significant arms supplier to the Sudanese government in Khartoum when the civil war was ongoing prior to South Sudan's secession in 2011. However, the political establishment in Juba recognises the importance of cooperating with China. ${ }^{47}$ The pragmatic attitude among South Sudanese leaders combined with China's preference 
for a top-down approach to its overseas development and security engagements implies that popular discontent with Chinese influence has limited influence on Beijing's ability to implement its policies in South Sudan.

In regional states, such as Ethiopia, China has developed special trade and economic cooperation zones, which allow for the improvement of poor infrastructure, inadequate services, and weak institutions by focusing efforts on a specific geographical area ${ }^{48}$ A special economic zone is a geographically demarcated area within a country, which functions with different administrative, regulatory and fiscal regimes compared to the rest of the country. The different rules applied in these zones usually concern investment conditions, taxation and international trade regulations. Usually, the rules aim to ensure that the business environment in demarcated zones is more liberal from a policy perspective, and that rules applied are more efficient from an administrative perspective than those prevailing in the rest of the domestic economy. As of 2014, China had established 19 special economic zones overseas. Of these, six are located in Africa: one in Zambia, one in Mauritius, two in Nigeria, one in Egypt, and one in Ethiopia. Addis Ababa hosts the only overseas zone in East Africa. ${ }^{49}$ China established the first private industrial zone in Ethiopia with the development since 2007 of the privately owned Eastern Industrial Zone (EIZ). Chinese partners in Ethiopia's special economic zone predominantly provide infrastructure financing and foreign direct investments. They also provide training and technical support on the development and management of the special economic zone. UN-sponsored research has revealed that in Ethiopia, delays in infrastructure and utility services development, such as access to electricity and water, are among the zone's main challenges. ${ }^{50}$ China's special economic zone has contributed to creating permanent local jobs, and working in the zone is considered an opportunity to acquire skills and generate income. The roles and responsibilities of the Ethiopian government and the Chinese investors are defined in memorandums of understanding (MoUs). As a result, both parties contribute to financing projects. ${ }^{51}$

The success of China's special economic zone in Ethiopia can be explained by a number of factors. First, special economic zones should fit into and benefit from specific local circumstances in line with China's principle that Africa must follow its own development path. Second, continuous government involvement in policy formulation and monitoring, and in the provision of infrastructure, is indispensable to the successful development of special economic zones. Third, a continuous focus on human resource development both in terms of expertise concerning special economic zones and in terms of possessing a skilled labour force, seems to have been a precondition of success in terms of contributing to economic development. The involvement of Ethiopian financial contributions and labour in China's development projects has helped ensure the success of the EIZ. ${ }^{52}$

Ethiopia is the second most populous African country after Nigeria. Ethiopia is also China's primary economic and strategic partner in East Africa. China has reservations regarding Kenya, the alternative to Ethiopia to receive preferential treatment. China's engagement in Kenya is limited due to concerns about corruption, 
crime, theft, disorder and safety. ${ }^{53}$ Ethiopia's position as China's primary partner has helped Addis Ababa build one of the strongest militaries in Africa, experience the fastest economic growth rate in Africa since 2006, and host the AU headquarters. As a regional centre for East Africa, Ethiopia aspires to become the regional hegemon. However, its regional neighbours do not see Ethiopia in this light because its regional policies are characterised by a historically determined bid for hegemony rather than by policies and initiatives taking into account East Africa's common interests. ${ }^{54}$ As China's strategic partner, Addis Ababa receives significant military and economic assistance without political conditionality constraints. Ethiopia maintains Western ties, using Chinese assistance as a bargaining chip in negotiations with European donors and vice versa. ${ }^{55}$

Recognising Ethiopia's lack of legitimacy as a regional power, China also supports other regional countries, as implied by Beijing's development of deep-water ports in Djibouti, Kenya and Tanzania and the construction of a regional rail corridor connecting Kenya, one of the African gateways to the maritime Silk Road, with Uganda, Burundi and South Sudan. ${ }^{56}$ Burundi, which is relatively resource-poor, has received Chinese financial support of US\$800 000 for its 2015 national elections. In addition, China has helped fund the construction of a new presidential palace and an electric power plant, and gives $97 \%$ of Burundi's exports to China duty-free access. ${ }^{57}$ China's assistance helps maintain a rough balance of power between Ethiopia and smaller economies, such as Tanzania, Kenya and Burundi.

Problems remain that should be addressed in China's regional trade and economic engagement. For example, Chinese firms should make greater effort to enhance localisation and offer more job opportunities for local workers. They should also work to protect emerging local industries and promote a trade balance between China and the region, according to Chinese observers. ${ }^{58}$ On the other hand, China is the only one among major donors that has pushed for industrialisation and related infrastructure improvement. As a result, China has produced or financed many of the paved roads, railroads and power plants in the region. This has filled a vacuum that has helped put in place basic preconditions for economic growth. In addition, the introduction of a special economic zone has attracted Chinese companies that have settled down, in particular in the industrialised and infrastructure sectors, thereby contributing to long-term economic development. ${ }^{59}$

\section{Diplomacy as an instrument of peace in a regional and global context}

Traditionally, China has distanced itself from involvement in regional political and military disputes. Departing from this position, China has been actively involved in diplomatic efforts to end South Sudan's civil war by mediating between the warring political factions. ${ }^{60}$ Responding to threats of United Nations Security Council (UNSC) sanctions, in August 2015, South Sudan's President Salva Kiir Mayardit and opposition fighters led by Riek Machar signed a peace deal, which made Machar vice-president. In April 2016, China donated US\$550 000 and office equipment to the UN-endorsed ceasefire monitoring body of South Sudan's newly 
formed unity government. ${ }^{61}$ In 2016, the peace agreement fell apart with the ouster of Vice-President Machar and the consolidation of the political and military power of President Salva Kiir Mayardit. It remains to be seen whether the peace process can be put back on track by a revised agreement between the contending political factions. ${ }^{62}$

A lack of other major powers willing to intervene combined with significant Chinese energy interests in South Sudan encouraged China to contribute to brokering peace. Beijing wanted to demonstrate that it is not merely protecting its national interests in South Sudan, but also takes seriously its commitment to be a responsible power obliged to promote peace and security and protect civilians against mass atrocities within the UN framework. ${ }^{63}$ China recognised the new regime in South Sudan when it obtained independence in 2011. Beijing took this decision because the new country emerged on the basis of a negotiated and voluntary decision assisted by the international community in the form of UN approval. The new political reality was not forced upon Sudan. Beijing does not oppose voluntary regime change ${ }^{64}$ Moreover, UNSC resolution 1996 specifically mentions that UNMISS was established on the basis of consent from the target state. ${ }^{65}$ Consequently, Chinese participation in UN initiatives in South Sudan does not violate Beijing's commitment to non-interference in principle. However, in practice, China's diplomatic ties with Juba following the 2005 Comprehensive Peace Agreement's establishment of two governing entities in Khartoum and Juba, respectively, represented a creative interpretation of non-interference, even if the principle was not breached. This development begs the question of how protection of China's investments can be reconciled with its policy of non-interference. ${ }^{66}$

The continued importance for China of non-interference and of regional positions on the legitimacy of this principle in the event of atrocities against civilians was demonstrated by Beijing's position on suggestions for deploying African peacekeepers in Burundi in 2015-16. Beijing supported the Burundian government's rejection of AU plans to deploy 5000 East African Standby Force (EASF) peacekeepers to protect civilians. The EASF mission was to ensure that the region has indigenous professional military forces to be deployed in regional hot spots. Institutionally, the EASF is a peacekeeping force under the AU, which has yet to be endorsed by the UNSC as deployable. Due to Burundian President Nkurunziza's objections, any deployment would require UNSC approval. Russia and China signalled that they would block any resolution infringing upon Burundi's sovereignty. Moreover, key EASF countries Rwanda and Tanzania announced that they would not contribute troops. Hence, China's position on intervention was in line with the attitude of key regional states.$^{67}$ To support a diplomatic solution, China has donated US\$200 000 to the East African Community (EAC) as part of efforts aimed at facilitating a Tanzania-led dialogue to resolve the political crisis in Burundi. ${ }^{68}$ 


\section{Conclusion}

In this article, I have used the English School as a basis for arguing that Chinese contributions to regional order in East Africa comprise:

- regulating the use of force in East Africa by means of peacekeeping;

- using economic development as a driver of stability and legitimacy; and

- using diplomatic institutions as instruments of reconciling Beijing's noninterference policy with the need for contributing to the management of security issues that threaten the common interest in peace and stability.

The English School has facilitated an analysis of how Beijing seeks to reconcile the dilemmas stemming from China's concern to preserve a state-based regional order in a region with growing demands for intervention. These growing demands are due to the prevalence of sub-state and transnational security issues in states with weak governmental institutions combined with considerable economic and social challenges.

The analysis has highlighted the dilemmas for countries involved in balancing order and justice. China experiences the dilemmas in Beijing's focus on order through the support of regime institutions and non-interference. This engenders challenges to justice by potentially allowing rogue regimes to jeopardise the basic security of individuals. In turn, these rogue regimes potentially challenge regional order by the spreading of instability and conflict across borders within the region. An example is the humanitarian crisis in South Sudan since 2016. China has focused on accommodating the secession of South Sudan from Sudan. This Chinese focus has involved contributing to the peace process and to economic development, relying heavily on interaction with the Juba government with reference to Beijing's noninterference policy. Beijing's approach diverts attention away from the ongoing deadly clashes between government and opposition forces set off by violence and displacements. The resulting refugee flows to neighbouring states trigger tensions and critical shortfalls in water, food, shelter, health, education and access to arable land. ${ }^{69}$ The inability of the UN to offer protection of civilians against atrocities illustrates that China's much publicised UN peacekeeping contributions do little to avert humanitarian crises.

Despite these reservations concerning China's contribution to regional order, Beijing's general objectives of promoting regional development and stability remain a focal point. China concentrates on facilitating economic growth and state stability by including East Africa in a global development and communications network based on the principles of non-interference and governmental consent. China's OBOR strategy constitutes a comprehensive approach to East Africa's development and stability. It is a nationally crafted strategy that combines governance, economic growth and security sector reform in the target countries with Chinese national interests. In addition, Beijing bases its comprehensive approach on East Africa's 
historical economic, institutional and political identity in addition to its national preferences and interests. The means of implementing the strategy are to build physical infrastructure, such as railways and ports, thereby contributing to economic growth, and Beijing supports the ability of governments to exercise sovereign authority on the basis of its preference for a state-centred approach based on noninterference. Although this approach does not always prevent humanitarian crises or ensure stability, its contributions to economic development and regime stability seem to have some positive effects on peace and security in East Africa that may help pave the way for future regional order.

\section{Endnotes}

${ }^{1}$ The author would like to thank Stellenbosch University and its staff at the Security Institute for Governance and Leadership in Africa for hosting me in November and December 2016 and for contributing with comments and sources for this article. Please note that the identities of people interviewed have been withheld to ensure their anonymity.

${ }^{2}$ East Africa is defined as the region consisting of Burundi, Comoros, Djibouti, Eritrea, Ethiopia, Kenya, Rwanda, Seychelles, Somalia, Sudan, South Sudan, Tanzania and Uganda, in accordance with the definition provided by the African Development Bank Group - see <http://www.afdb.org/en/ countries/east-africa/ $\geq$ Accessed on 25 November 2016.

${ }^{3}$ M Duchâtel, R Gowan \& ML Rapnouil. Into Africa: China's global security shift. Policy brief. London: European Council on Foreign Relations. June 2016. $<$ http://www.ecfr.eu/publications/summary/into_africa_chinas_global_ security_shift $>$ Accessed on 25 November 2016.

${ }^{4}$ A seminal work is $\mathrm{H}$ Bull. The anarchical society: A study of order in world politics ( $2^{\text {nd }}$ ed). London: Macmillan, 1995.

${ }^{5}$ FS Northedge. The international political system. London: Faber \& Faber, 1976, 283-285.

${ }^{6}$ Ibid., pp. 112-113, 150-151.

${ }^{7}$ Bull. 1995, op.cit., 65-68.

${ }^{8}$ M Wight. Systems of states. Leicester: Leicester University Press, 1977, 153.

${ }^{9} \mathrm{H}$ Bull. "Order vs. justice in international society". Political Studies XIX/3. September 1971. 269-283.

${ }^{10} \mathrm{C}$ Holbraad. The Concert of Europe: A Study in German and British international society, 1815-1914. Harlow: Longmans, 1970.

${ }^{11}$ CAW Manning. The nature of international society. London: MacMillan, 1975, 160-161, 176-177.

${ }^{12}$ L Odgaard. China and Coexistence: Beijing's National Security Strategy for the Twenty-First Century. Washington, DC: Woodrow Wilson Center Press/Johns Hopkins University Press, 2012.

${ }^{13}$ A Guidetti. "Confront or accommodate? The Maritime Silk Road will test USChina rivalries". Global Asia 10/3. Fall 2015. 43.

${ }^{14}$ Interview with university scholar, Beijing, 15 October 2015. 
${ }^{15} \mathrm{X}$ Li. "Understanding China’s economic success: Embeddedness with Chinese characteristics". Asian Culture and History 8/2. 2016. 18-31.

${ }^{16}$ Presentation by think tank scholar, Beijing, 12 October 2015.

${ }^{17}$ Ibid.; interview with AV Kortunov, Russian International Affairs Council, Moscow, 4 April 2016.

${ }^{18}$ P Carmody \& I Taylor. "Flexigemony and force in China's resource diplomacy in Africa: Sudan and Zambia compared". Geopolitics 15. 2010. 497.

${ }^{19}$ Interview with PLA officer, Beijing, 19 October 2015.

${ }^{20}$ M Clemens. "The Maritime Silk Road and the PLA: Part Two". China Brief 15/7. 3 April 2015. <http://www.jamestown.org/single/?tx_ttnews\%5Btt_ news $\% 5 \mathrm{D}=43748 \&$ no_cache $=1 \#$.Vz2cJTWLRdg $>$ Accessed on 25 November 2016.

${ }^{21}$ Interview with Secretary General Yang Yi, China Institute of International Studies, Beijing, 20 January 2015.

${ }^{22}$ T Bwambale. "China to expand peacekeeping role in Africa". New Vision. 25 August 2016. <http://www.newvision.co.ug/new_vision/news/1433624/ china-expand-peacekeeping-role-africa> Accessed on 25 November 2016.

23 "China's helicopter unit joins peacekeeping mission in Darfur". Xinhua. 11 June 2017. <http://www.xinhuanet.com/english/2017-06/11/c_136357212.htm> Accessed 5 December 2016.

${ }^{24}$ W Sun. "China dispatches 2,609 policemen for UN peacekeeping missions, most among permanent members".People's Daily Online. 25 September 2017. < http://en.people.cn/n3/2017/0925/c90000-9273387.html> Accessed 5 December 2018.

25 "China continues financial support for AMISOM". African Defense. 11 December 2015. <http://www.african-defense.com/defense-news/china-continuesfinancial-support-for-amisom/> Accessed on 25 November 2016.

26 "Full text: China's second Africa policy paper". Xinhua. 4 December 2015. $<$ http://news.xinhuanet.com/english/2015-12/04/c_134886545.htm> Accessed on 25 November 2016.

${ }^{27}$ Y-S Wu. "African Union's planned overhaul may affect its ties with China". University of Witwatersrand, 24 February 2017. < https://www.wits.ac.za/ news/latest-news/in-their-own-words/2017/2017-02/african-unionsplanned-overhaul-may-affect-its-ties-with-china.html $>$ Accessed on 14 August 2017.

${ }^{28}$ C Alden. "China and Africa: The relationship matures". Strategic Analysis 36/5. 2012. 701-707.

${ }^{29}$ JD Durson. "China's rising near this key US war base: Here's how we push back". Defense One. 26 July 2016. <http://www.defenseone.com/ideas/2016/07/ US-china-djibouti/130221/> Accessed on 25 November 2016.

${ }^{30}$ A Panda. "After Djibouti base, China eyes additional overseas military 'facilities"'. The Diplomat. 9 March 2016. <http://thediplomat. com/2016/03/after-djibouti-base-china-eyes-additional-overseas-militaryfacilities/> Accessed on 25 November 2016. 
${ }^{31}$ The Information Office of the State Council. "Full text: China's military strategy". Reprinted in China Daily. 24 May 2015. <http://www. chinadaily.com.cn/china/2015-05/26/content_20820628_4.htm> Accessed on 25 November 2016.

${ }^{32}$ A Soliman \& D Styan. "Djibouti's people have yet to benefit from its growing importance". Chatham House. 15 April 2016. <https://www. chathamhouse.org/expert/comment/djibouti-s-people-have-yet-benefit-itsgrowing-importance\#> Accessed on 25 November 2016.

${ }^{33}$ On China's defensive posture, see L. Odgaard \& S. Lund. "Denmark's and China's Contributions to Development and Stability in East Africa", in L. Odgaard \& S. Liu (eds.). Danish and Chinese Perspectives on the Objectives of United Nations Missions: Proceedings from the Second Joint AMS-RDDC Seminar on Peacekeeping at AMS in Beijing 14 June 2016. Copenhagen: Royal Danish Defence College, 2016, pp. 24-34. On institutions, see Deborah Bräutigam. China, Africa and the International Aid Architecture. Tunis: African Development Bank. Working Paper No. 107. April 2010, pp. 17-38.

${ }^{34}$ R Zongze. 'Responsible protection: Building a safer world". China Institute of International Studies. 15 June 2012. <http://www.ciis.org.cn/ english/2012-06/15/content_5090912.htm>. Accessed on 19 December 2017; interview with university scholar, Beijing, 23 January 2015.

35 “China continues peacekeeping mission in Sudan”. Xinhua/China Daily.

18 September 2007. <https://www.chinadaily.com.cn/china/2007-09/18/ content 6115402.htm $>$ Accessed on 19 December 2017.

36 "China to send 700 combat troops to Sudan". The Guardian. 23 December 2014. $<$ https://www.theguardian.com/world/2014/dec/23/china-700-combattroops-south-sudan-africa-battalion-un-peacekeeping > Accessed on 19 December 2017.

37 “China sends first infantry battalion for UN peacekeeping”. Xinhua. 22 December 2014. <http://news.xinhuanet.com/english/china/201412/22/c_133871006.htm> Accessed on 25 November 2016.

${ }^{38}$ Interview with peacekeeping police officer, Langfang, China, 19 January 2015.

39 "China continues financial support for AMISOM" op. cit.

${ }^{40} \mathrm{~T}$ Mandrup. "The African Standby Force and regional security integration: The case of the East African Standby Force". Updated version of paper, presented at seminar on East African security, Copenhagen University, Copenhagen, 1 February 2016.

${ }^{41}$ S Tiezzi. "UN report: China sold \$20 million in arms and ammunition to South Sudan”. The Diplomat. 27 August 2015. <http://hediplomat.com/2015/08/ un-report-china-sold-20-million-in-arms-and-ammunition-to-southsudan/> Accessed on 25 November 2016.

${ }^{42}$ Duchâtel et al. op. cit., p. 11.

${ }^{43}$ Interview with peacekeeping police officer op. cit.

${ }^{44}$ Y Sun. "Africa in China's foreign policy". Brookings. April 2014. <https://www. brookings.edu/wp-content/uploads/2016/06/Africa-in-China-web_CMG7.pdf> Accessed on 14 August 2017. 
${ }^{45}$ C Alessi \& B Xu. "China in Africa”. Council on Foreign Relations. 27 April 2015. $<$ http://www.cfr.org/china/china-africa/p9557> Accessed on 25 November 2016.

${ }^{46}$ A Vasselier. "Chinese foreign policy in South Sudan: The view from the ground". China Brief: The Jamestown Foundation 16/13. 22 August 2016. 15-19; interview with R Anthony, Director of the Centre for Chinese Studies, Stellenbosch University, 23 November 2016.

${ }^{47}$ Interview with R Anthony op. cit.

${ }^{48}$ D Bräutigam. "Africa's Eastern promise: What the West can learn from Chinese investment in Africa”. Foreign Affairs. 5 January 2010. $<$ https://www. foreignaffairs.com/articles/africa/2010-01-05/africa-s-eastern-promise> Accessed on 25 November 2016.

${ }^{49}$ D Bräutigam \& X Tang. “'Going global in groups’: Structural transformation and China's Special economic zones overseas". World Development 63. November 2014. 78-91; NS António \& S Ma. "China’s Special Economic Zone in Africa: Context, Motivations and Progress". Euro Asia Journal of Management. Issue 44. Vol. 25. No. 1/2. December 2015. 79-193. P. 86.

${ }^{50}$ United Nations Development Programme. "Comparative study on special economic zones in Africa and China". Working paper series, no. 6. Beijing: International Poverty Reduction Center in China and United Nations Development Programme China. 2015. <http://www.cn.undp. org/content/dam/china/docs/Publications/UNDP-CH-Comparative $\% 20$ Study\%20on\%20SEZs\%20in\%20Africa\%20and\%20China\%20-\%20ENG.

${ }^{51}$ Ibid. pdf> Accessed on 25 November 2016.

${ }^{52}$ Ibid., p. 55.

${ }^{53}$ E Nyandong. "Perception Index: How Kenya is viewed by major Chinese investors". Diplomat East Africa. February 2015. 33-34.

${ }^{54}$ Mandrup op. cit.

${ }^{55}$ DH Shinn. "Ethiopia and China: How two former empires connected". International Policy Digest 1/6. June 2014. 29-37; F Cheru. "Emerging Southern powers and new forms of South-South cooperation: Ethiopia's strategic engagement with China and India”. Third World Quarterly 37/4. $592-610$.

${ }^{56}$ AC-H Lim. "Africa and China's $21^{\text {st }}$ century Maritime Silk Road". The AsiaPacific Journal Vol. 13. Issue 11. No. 3. 16 March 2015. 1-19.

57 "China makes new aid pledges". The Economist Intelligence Unit. 23 September 2014. <http://country.eiu.com/article aspx?articleid=822306866\&Coun try $=$ Burundi\&topic $=$ Politics\&subtopic $=F \_4>$ Accessed on 25 November 2016.

${ }^{58} \mathrm{H}$ Wenping. "Rationality is key to assess Sino-African ties". Global Times. 1 August 2016. <http://www.globaltimes.cn/content/997582.shtml> Accessed on 25 November 2016.

${ }^{59}$ C Cheng. "G20 pledges African industrialization support". Global Times. 25 September 2016. <http://www.globaltimes.cn/content/1008181.shtml> Accessed on 25 November 2016. 
${ }^{60}$ Ministry of Foreign Affairs of the People’s Republic of China. "Foreign Ministry spokesperson Hong Lei's regular press conference on June 3, 2014". 3 June 2014. <http://www.fmprc.gov.cn/mfa_eng/xwfw_665399/ s2510_665401/2511_665403/t1161810.shtml $>$ Accessed on 25 November 2016.

${ }_{61}$ "China donates Sh55m to boost South Sudan peace process”. Daily Nation. 2 May 2016. <http://www.nation.co.ke/news/world/China-donates-Sh55m-toboost-South-Sudan-peace-process/-/1068/3184862/-/6efhxwz/-/index. html $>$ Accessed on 25 November 2016.

${ }^{62}$ H Laugesen. "Ny magtfordeling tegner sig i Sydsudan" [New distribution of power is emerging in South Sudan]. Globalnyt 23/28. 15 August 2016. $<$ https:/globalnyt.dk/content/ny-magtfordeling-tegner-sig-i-sydsudan> Accessed on 25 November 2016.

${ }^{63} \mathrm{~S}$ Tiezzi. "China in South Sudan: Practical responsibility". The Diplomat. 13 January 2015. <http://thediplomat.com/2015/01/china-in-south-sudanpractical-responsibility/> Accessed on 25 November 2016.

${ }^{64}$ Z Xiang. "China recognizes independence of South Sudan”. Xinhua. 9 July 2011. $<$ http://news.xinhuanet.com/english2010/china/2011-07/09/c_13975300. htm $>$ Accessed on 25 November 2016.

${ }^{65}$ United Nations Security Council. "Resolution 1996 (2011)”, S/RES/1996 (2011), 8 July 2011. <http://www.un.org/en/peacekeeping/missions/past/unmis/ documents/sres1996_2011.pdf $>$ Accessed on 25 November 2016.

${ }^{66}$ D Large. "China's Sudan engagement: Changing Northern and Southern political trajectories in peace and war". The China Quarterly 199. September 2009. 621-623.

${ }^{67} \mathrm{~S}$ Okiror. "Briefing: What next for the Burundi peace process". IRIN. 4 January 2016. <http:/www.irinnews.org/analysis/2016/01/04/briefing-what-nextburundi-peace-process $>$ Accessed on 25 November 2016.

${ }^{68}$ ARA Shaban. "China donates $\$ 200,000$ to EAC towards Burundi political dialogue". africanews. 26 September 2016. <http://www.africanews. com/2016/09/26/china-donates-200000-to-eac-towards-burundi-politicaldialogue/> Accessed on 25 November 2016.

${ }^{69}$ UNHCR. "South Sudan Regional Refugee Response Plan: January-December 2017'. December 2016. <http://www.unhcr.org/partners/ donors/589497987/2017-south-sudan-regional-refugee-response-planjanuary-december-2017-23.html> Accessed on 14 August 2017. 